\title{
Utilization of Precast Concrete Panels for Fast Construction of Outer Wall of LNG Storage Tanks
}

\author{
Hyeon Cheol Jo', Jun Hwi Kim², Seul Kee Lee², Kang Won Lee², Seung Hyun Oh${ }^{3}$, Yun Mook Lim \\ ${ }^{1}$ Department of Civil and Environmental Engineering, Yonsei University \\ 50, Yonsei-ro, Seodaemun-gu, Seoul, Republic of Korea \\ brown1988@yonsei.ac.kr; yunmook@yonsei.ac.kr \\ ${ }^{2}$ LNG Tech Center, KOGAS \\ 960, Incheonsinhang-daero, Yeonsu-gu, Incheon, Republic of Korea \\ seulkee@kogas.or.kr; kale@kogas.or.kr; zzoondse@kogas.or.kr \\ ${ }^{3}$ Research \& Development, JANGHEON Engineering \& Construction \\ 554, Ogeum-ro, Songpa-gu, Seoul, Republic of Korea \\ osh3201@naver.com
}

\section{Extended Abstract}

The concrete outer wall of the conventional LNG storage tanks has been constructed with cast-in-place concrete method. This method involves a series of procedures, such as arranging reinforcing bars, installing formwork, pouring concrete, and curing from the bottom to the top of the wall [1]. However, cast-in-place concrete method is difficult for construction management because it is significantly affected by conditions of construction site, such as climate conditions and material supply conditions. Therefore, this construction method consumes construction time and cost. Recently, to reduce the construction time, various construction methods, such as jump-form and slip-form method, are being applied to the concrete outer wall of LNG storage tanks. Although these methods can reduce the construction time of outer wall tank, there is a limit that construction of the inner tank has to be conducted after construction of concrete outer tank is completed.

Meanwhile, precast concrete (PC) method, developed in this research, has some different characteristics compared with that of cast-in-place concrete method. In the full PC method, structural members are previously manufactured at a factory and transported to the construction site to be assembled. There are advantages which are reduction of construction time and cost and improvement on quality control and durability [2]. Also, as demands for LNG steadily increase, techniques using PC method are being developed for fast construction of LNG storage tanks. Thus, these construction techniques are expected to further develop to build LNG storage tanks more easily in areas where climate conditions are not favourable or raw materials are not sufficient.

The main objectives of this paper are to introduce the new construction method for concrete outer wall of LNG storage tanks using partial PC panels to overcome the existing limitations, and discuss the benefits of the technology. In summary, the new construction method has an advantage that it can construct inner tank and outer tank at the same time by using free-standing wall of steel liner [3]. In this method, the steel liner, so called vapour barrier, is used as a permanent formwork on the inside and PC panels are used as a permanent formwork on the outside of outer wall [4]-[6]. In addition, to verify the applicability of the new construction method, a mock-up test was conducted considering PC panels and steel liner. During this mock-up test, to check the constructivity with partially constructed for full size of outer wall tank, the displacement and strain of steel liner are measured and the constructability was checked.

\section{References}

[1] Y. M. Yang, J. H. Kim, H. S. Seo, K. W. Lee, I. S. Yoon, "Development of the world's largest above-ground full containment LNG storage tank," 23rd World Gas Conference, Amsterdam, 2006.

[2] K. Hjorteset, M. Wernli, M. W. LaNier, K. A. Hoyle, W. H. Oliver, "Development of large-scale precast, prestressed concrete liquefied natural gas storage tanks," PCI Journal, vol. 58, no. 4, pp. 40-54, 2013.

[3] CANTONI SRL, "The third way to build a tank," Tank Storage, 2013. 
[4] D. M. Morrison, J. R. Simmons, D. R. Butts, "Use of partial precast panels for construction of concrete walls and shells," U.S. Patent 7162844 B2, 2007.

[5] J. R. Simmons, P. Dyson, "Method of constructing a storage tank for cryogenic liquids," U.S. Patent 8603375 B2, 2013.

[6] S. J. Jeon, B. M. Jin, Y. J. Kim, "A study on the methods for shortening the construction period of LNG storage tanks," Korea Concrete Institute, pp. 931-932, 2014. 